\title{
SMALL FIRM INTERNET ADOPTION: A MARKET ORIENTED APPROACH
}

\author{
Colin Jones \\ University of Tasmania \\ School of Management

Sandy Bay
Tasmania 7005
Australia
phone: +61 (0) 362262826
fax: +61(0) 36226 2808
Colin.Jones@utas.edu.au
$(*)=$ Contact Author

\author{
Dr Rob Hecker \\ University of Tasmania \\ School of Management \\ Sandy Bay \\ Tasmania 7005 \\ Australia \\ phone: +61 (0) 362261174 Victoria 3800 \\ fax: +61 (0) 362262808 \\ Rob.Hecker@utas.edu.au \\ Dr Peter Holland \\ Monash University \\ Department of Management \\ PO Box 152-16 Faculty of Business and \\ Economics \\ Wellington Road \\ Clayton \\ Australia \\ phone: +61 (0) 399052329 \\ fax: +61 (0) 399055412 \\ Peter.Holland@BusEco.monash.edu.au
}

\begin{abstract}
Fundamental to the development of new customer value offerings via web-based commerce is a small firm's ability to strategically acquire and exploit knowledge. The focus of this paper is the empirical testing of a normative web-based commerce adoption model developed from a review of the extant literature related to electronic marketing, the Internet and the diffusion of new innovations. A preliminary test of the model's theoretical contentions lent support to its overall focus, but found that the firm's existing learning capabilities were diminished during the adoption of webbased commerce. Consequently, sub-optimal adoption outcomes were associated with insufficient knowledge development.
\end{abstract}

Key Words: Web-based Commerce, Small Firms, Internet Adoption, and Market Orientation

\section{INTRODUCTION}

Since the mainstream adoption of the Internet by Australian consumers (post 1996), there has been continual and marked increases in household participation, with $33 \%$ of all Australian households having Internet access as at May 2000, a 53\% increase over May 1999 (ABS, 1999). At July 2001, 75\% of small firms, defined as having 19 or less employees (McLennan, 1999) were similarly connected to the Internet (Yellow Pages Business Index, 2001). Despite the high 'Internet implementation' rates by small firms, only $27 \%$ utilise the medium to advertise their products online, a mere $19 \%$ accept online orders, and only $13 \%$ offer an on-line payment service for their customers (Yellow Pages Business Index, 2001). This is in stark contrast to small firm usage of the Internet for e-mail (82\%) and general research purposes (65\%) (Yellow Pages Business Index, 2001). Interestingly, and despite the apparent low actual usage rates for small businesses to date, $62 \%$ of Australian small firms yet to introduce the Internet into their operations, stated their imminent intention to become an online business (Yellow Pages Business Index, 2001). Given these base statistics, there appears to be a significant discrepancy between the levels of commercial Internet adoption and its contribution to incremental firm growth. A review of the literature indicates that although the potential benefits of web-based commerce are well documented (e.g. Armstrong \& Hagel, 1996; Hamill, 1997; Hoffman \& Novak, 1997), there is a paucity of research dealing with the generic issue of how to effectively implement web-based commerce into a small firm's operations. Six specific areas deemed central to the adoption and effective implementation of web-based commerce were identified. The six areas, integral to the proposed normative web-based adoption model are as follows; 1) Web-based Commerce Adoption Drivers; 2) Market Orientation; 3) Cooperative Behaviours; 4) Web-based Business Models; 5) Value Chain Reconfiguration; and 6) Web-based Value. Through a synthesis of the literature, a normative and generic adoption model for small firm web-based commerce was developed.

\section{PROPOSED NORMATIVE WEB-BASED COMMERCE ADOPTION MODEL}

The model sought to combine components available to small businesses, therefore increasing possible acceptance of the model beyond specific industry characteristics. As such, this research sought to make two specific contributions. Firstly, to provide a generic adoption model for small firms with regard to the strategic implementation of web-based commerce into their overall business strategy. Secondly, to identify sources of potential difficulty and inefficiency in the actual implementation of a web-based commerce strategy for small firms.

\section{Web-based commerce adoption drivers}

Previous research into small firm adoption of web-based commerce has identified the medium's perceived benefits as the primary motivator (e.g. Poon \& Strom, 1997; Poon \& Swatman, 1999). Rogers (1995) argues that 
successful adoption of complex innovations requires a knowledge base beyond 'mere awareness' of perceived benefits. During stage one (see Figure 1 below) of the of the adoption model, it is predicted that firms gain an awareness of the perceived benefits of web-based commerce through exposure to the hype that surrounds the medium, and change agents (such as Internet service providers [ISPs]) who promote it's virtues.

Figure 1: The Normative Web-based Commerce Adoption Model - Stage 1

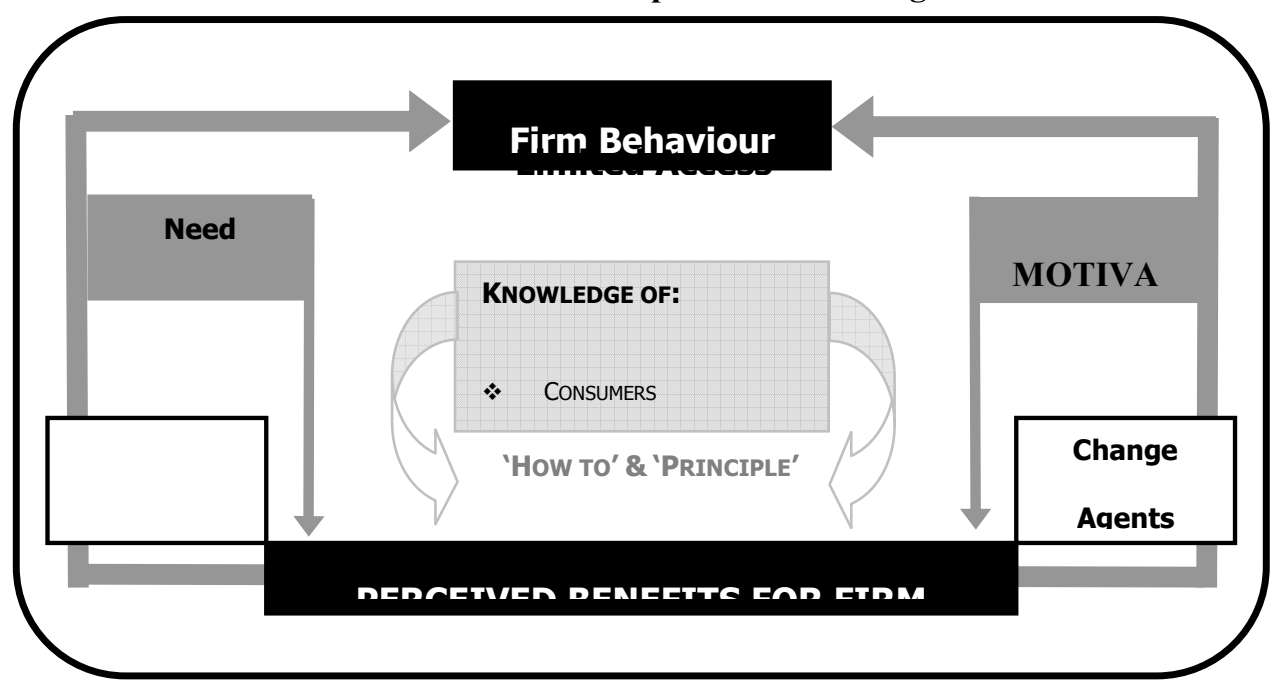

However, complex innovations, such as the Internet, require a knowledge base far exceeding awareness knowledge to (1) appreciate its possible application, and (2) reduce the possibility of misuse. Rogers (1995) states that adopters must acquire a higher knowledge base comprising 'how to' and 'principle' knowledge. 'How to' knowledge provides web-based commerce adopters with an understanding of how to use the innovation effectively, and 'principle' knowledge refers to the theoretical underpinnings of the innovation. Therefore, while awareness of the innovation may provide a possible 'e-vision' (Sawhney \& Zabin, 2001), it is the acquisition of 'how to' and 'principle' knowledge that underwrites its successful implementation (Rogers, 1995).

\section{Market Orientation}

The literature supports the reliance upon market orientation during the adoption of technological innovations by firms to enhance organisational learning (Glazer, 1991; Hoffman \& Novak, 1997; Morgan, Katsikeas \& AppuhAdu, 1998). Therefore, during stage two (see Figure 2 below), it is argued that market orientated firms will access the required 'how to' and 'principle' knowledge needed to successfully adopt web-based commerce.

Figure 2: The Normative Web-based Commerce Adoption Model: Stage - 2

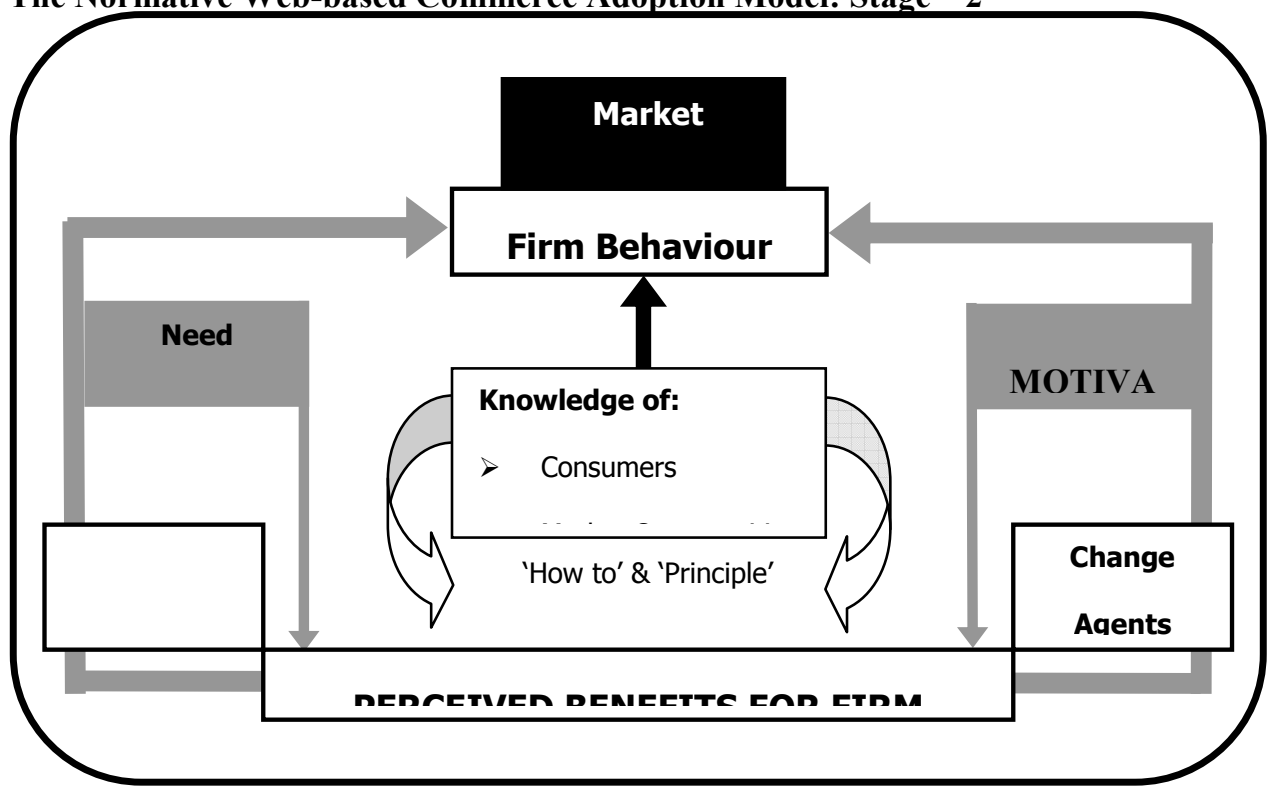


The seminal work of Hoffman and Novak (1997) associates market-orientated firm behaviour with the development of a future web-based competitive advantage due to its ability to provide firm access to customer, market and technology intelligence. Glazer (1991) also proposed the use of a firm's market orientation to facilitate increased access to intelligence in information intense markets. In proposing market orientation as a defendable resource system, Hunt and Morgan (1995, p 11) define a firm's market orientation to be:

(1) the systematic gathering of information on customers and competitors, both present and potential, (2) the systematic analysis of the information for the purposes of developing market knowledge, and (3) the systematic use of such knowledge to guide strategy recognition, understanding, creation, selection, implementation, and modification .

Our contention is that such knowledge processes are a prerequisite for successful adoption of a complex technological innovation. In summary, stage two suggests that without access to specific knowledge of customers, technology and the marketplace, the firm's adoption of web-based commerce will be less than optimal.

\section{Cooperative Behaviours}

Stage three, as illustrated in Figure 3, proposes the engagement of cooperative behaviours to share information through which the business's knowledge base is expanded. McWilliams and Gray (1995) and Lado, Boyd and Hanlon (1997) propose the use of cooperative strategies (e.g. logistics, payment \& referrals) to overcome resource weaknesses that restrict the implementation of resource strengths. Small firms in the possession of 'how to' and 'principle' knowledge may require assistance to access the benefits of web-based commerce due a possible lack expertise and/or time and financial resources.

Figure 3: The Normative Web-based Commerce Adoption Model: Stage - 3

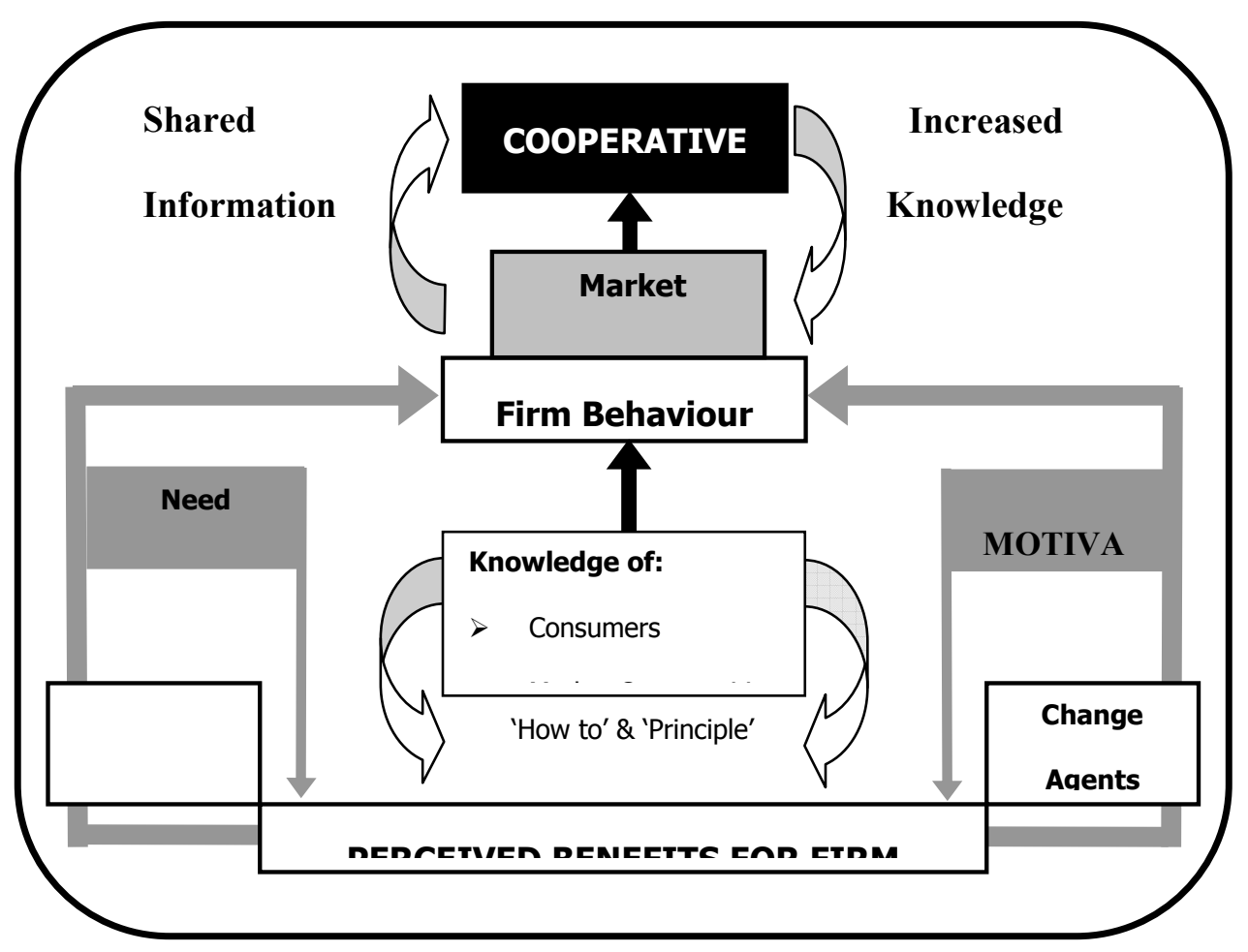

Hoffman and Novak (1997) propose the development of a cooperative rather than competitive approach to competitors to maintain a market orientation during web-based commerce adoption. Complementary relationships with other firms are recommended to create additional value through new and innovative resource structures (Brandenburger \& Nalebuff, 1995). Rayport and Jaworski (2001) also support the use of partnerships and strategic alliances which allow web-based firms to focus on their core competencies while developing resource clusters that enhance overall firm capabilities. However, during this process, the firm's value chain and business model may be subject to a process of reconfiguration (Timmers, 1998), requiring increased knowledge of customers' desired benefits, technological capabilities and markets (Rayport \& Jaworski, 2001). 
Stage three demonstrates the use of the firm's market orientation to share information and acquire new knowledge of customer needs, technological potential, and marketplace opportunities. This increases the ability to acquire the 'how to' and 'principle' knowledge required for the adoption of web-based commerce. Cooperation at this stage, especially for small firms is vital given that the acquisition of information for webbased commerce may well represent a novel and therefore challenging area of knowledge development with regard a firm's absorptive capacity (Cohen \& Liventhal, 1990).

\section{Web-based Business Models}

As a result of additional cooperative strategies, two issues related to the firm's business model/s arise. Firstly, the introduction of new firm strategies will require consideration of the existing operating structures, and secondly, the potential reconfiguration of the value chain may impact on a firm's ability to access vital sources of intelligence. As illustrated in Figure 4, stage four contends that as strategy changes, so must structure (Mintzberg, 1990), and the firm's market orientation is the key resource system upon which the new business model is determined.

Rayport and Jaworski (2001) state that a high quality web-based business model should meet the following criteria; it must be unique, provide links between capabilities and benefits, support links between firm activities and capabilities, be mutually reinforcing, provide a link between the physical world and the virtual world, and lastly, the resource must be capable of supporting a sustainable advantage. As such, a firm's market orientation may potentially provide an efficient resource to small firms whom typically have scarce resources (Chappell \& Feindt, 1999) and simple operating structures (Peterson, 1989; Sanchez, 1997; Chau \& Pederson, 2000).

Figure 4: The Normative Web-based Commerce Adoption Model: Stage -4

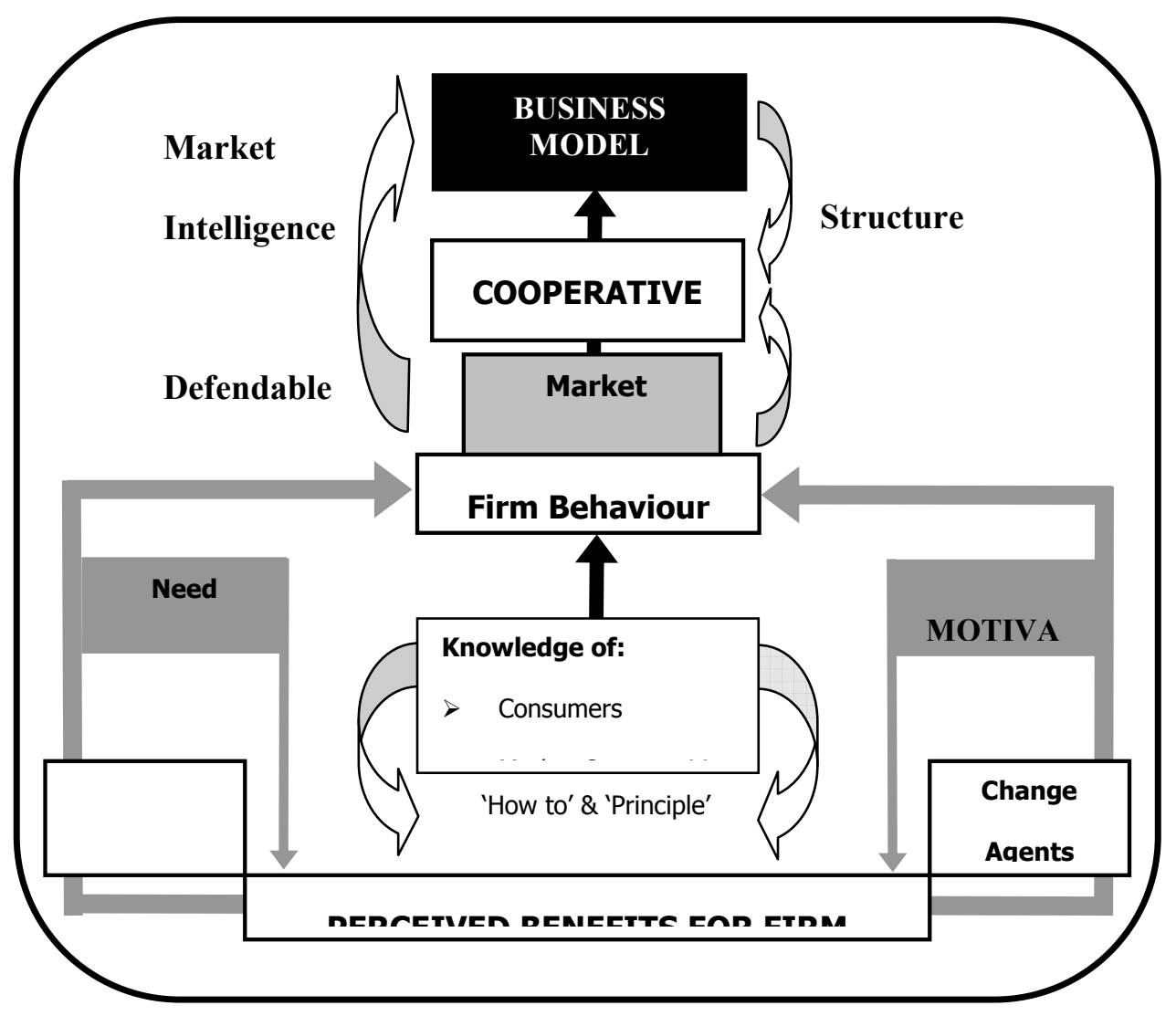

Consequently, such a web-based business model would be well placed to use market intelligence to develop capabilities that supported the value propositions so central to its function. Stage four illustrates that as knowledge is gained and used cooperatively, the firm's structure is altered to accommodate and support new firm capabilities. Therefore, knowledge and the coordination of the resources are the focal drivers of business model transformation. 


\section{Value Chain Reconfiguration}

Stage five, as illustrated in Figure 5 below, proposes the introduction of new value creating activities to satisfy the identified desired benefits of the target market/s. In line with market orientation theory, the challenge for firms during the introduction of web-based commerce, is to remain connected to customers and responsive to market opportunities (Day, 1999).

Figure 5: The Normative Web-based Commerce Adoption Model: Stage - 5

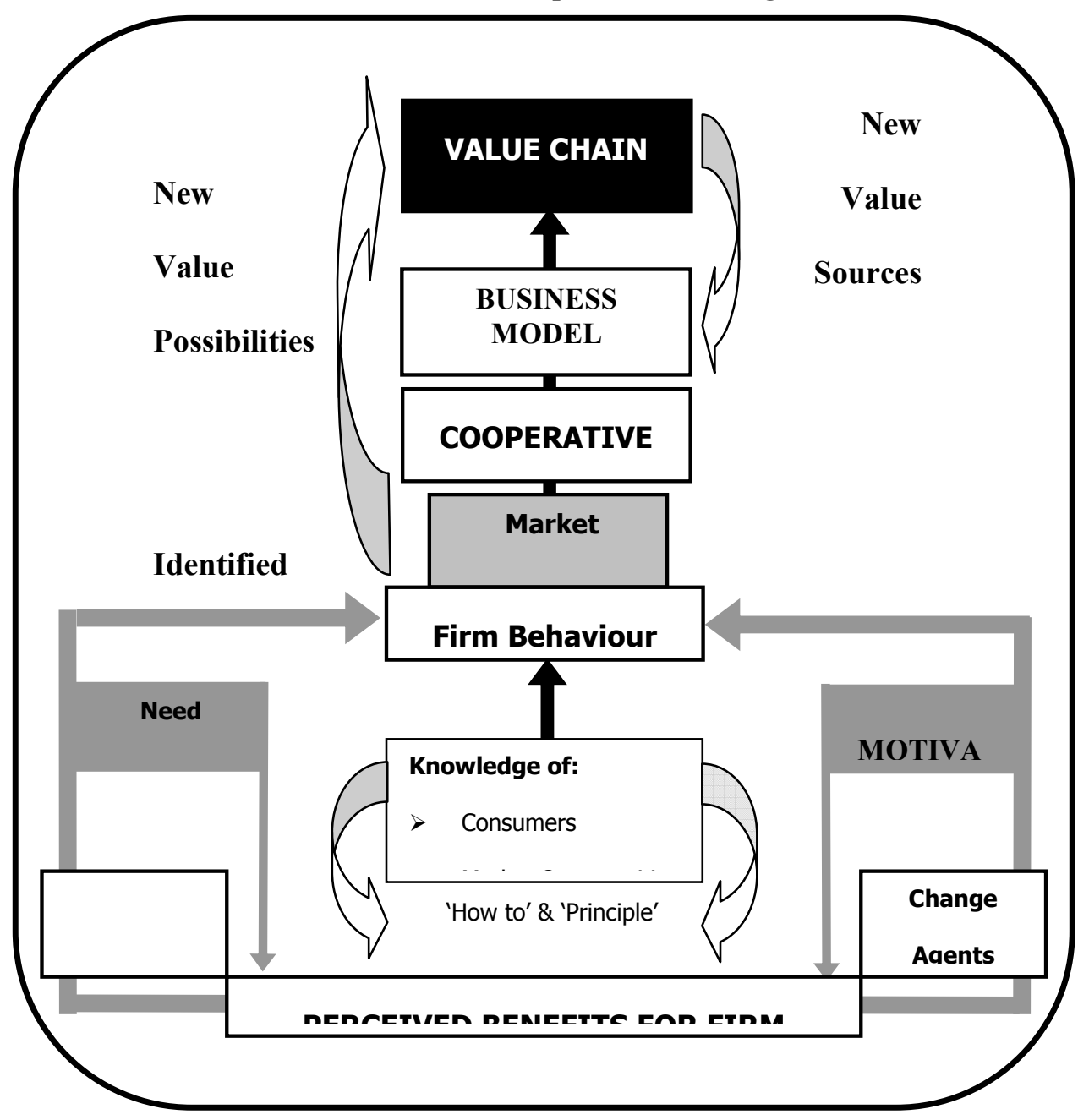

Under conditions of technological change, there is a greater likelihood that the link between firm offerings and customer needs may become divergent (Slater \& Narver, 1994; Enders \& Jelassi, 2000). To develop value offerings that complement the business model, Timmers (1998) and Afuah and Tucci (2001) argue for the reconfiguration of the traditional value chain (Porter, 1985) to access to new sources of web-based value.

The model to date suggests that market orientated firms who reconstruct their value systems, may create value through the alignment of business strategy and structure with an explicit understanding of the buyers of their offerings (see Drucker, 1985; Slater \& Narver, 1998). During such a process, business model development may liberate 'trapped value' i.e. value gained from market and value system efficiencies, and/or introduce 'new-tothe-world value' i.e. new value through customisation and personalisation (Rayport \& Jaworski, 2001). In summary, the model assumes the firm has now acquired 'how to' and 'principle' knowledge through its market orientation, identifying desired customer benefits which require new firm capabilities, resulting in the need to reconfigure the value chain, to access new web-based value. 


\section{Web-based Value}

Within the normative adoption models development thus far (see Figure 6 over page), the firm's market orientated behaviours are posited to be central to developing a web-based value proposition. That is, in terms of the development of firm capabilities through cooperative actions and access to new value creating activities/architecture to supplement the 'traditional' activities of the value chain. Four sources of web-based value have been identified as efficiency, complementarities, lock-in and novelty (Amit \& Zott, 2001). The value sources are dependent upon two important factors. Firstly, a synergistic relationship exists between the sources requiring a need to develop all four to enhance the value of each individual source. Secondly, their contributions to a competitive advantage are premised upon mutual gains between the firm and customer. Therefore, all are dependent on increased levels of strategic customer, market and technology knowledge.

Figure 6: The Normative Web-based Commerce Adoption Model

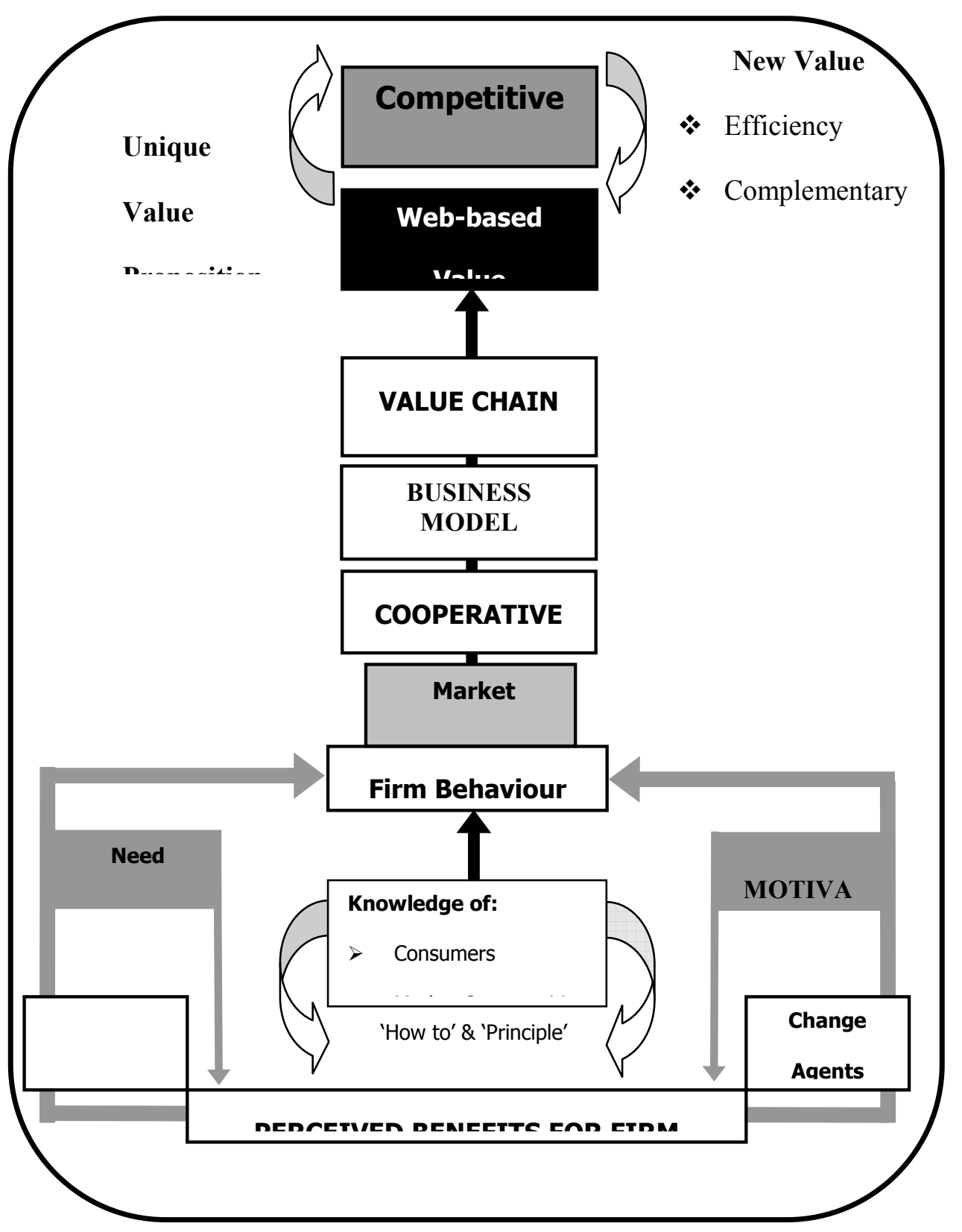

Given the noted discrepancy between Internet implementation and its integration into activities supportive of incremental growth, a clear opportunity to empirically test the developed normative best-practice adoption model. 


\section{RESEARCH METHOD}

Due to the exploratory nature of the research, a multiple case study design (Yin, 1994) of in-depth interviews with five small firms to explore the adoption of web-base commerce within a real-life context. The research aims were to observe the degree of congruence between firm adoption of web-based commerce and the proposed model, and to identify difficulties experienced and value received. Given the proposed importance of market orientation to the adoption model's construction, Pelham and Wilson's (1996) small and medium firm specific market orientation scale was used to measure the degree of pre- (traditional commerce) and post-adoption (webbased commerce) market orientation. A judgemental sampling approach (Babbie, 1999) enabled the cases to be selected via a selection criterion that enhanced the research aim of observing the influence of an intangible firm resource (market orientation) during the adoption of web-based commerce and the development of new value creating activities. The firms met the following criteria: all had served domestic, interstate and international markets in excess of five years, web-based commerce supplemented their existing operations, and their web site facilitated customer service, marketing communications and the exchange of a physical product.

\section{THE FINDINGS}

The findings of this preliminary research are that the five firms did not follow the normative adoption model arising from the synthesis of the literature review. There was however support for the theoretical contentions of some discrete stages within the model. Most notably, the influence of perceived benefits. Table 1 illustrates that the relative degree of market orientation measured (with the exception of one) was less for web-based commerce in contrast to 'traditional' commerce, ranging from $-2.25 \%$ to $-28 \%$.

Table 1: Description of Firms

\begin{tabular}{|l|c|c|c|c|c|}
\cline { 2 - 6 } \multicolumn{1}{c|}{} & Firm A & Firm B & Firm C & Firm D & Firm E \\
\hline Industry & $\begin{array}{c}\text { Book } \\
\text { Publishing }\end{array}$ & $\begin{array}{c}\text { Children's } \\
\text { Footwear }\end{array}$ & Winemaker & $\begin{array}{c}\text { Whisky } \\
\text { Distiller }\end{array}$ & $\begin{array}{c}\text { Knitwear } \\
\text { Manufacturer }\end{array}$ \\
\hline Adoption Year & 1996 & 1997 & 198 & 1995 & 1998 \\
\hline Initial Motivation & Change Agent & Change Agent & Change Agent & Hype & Hype \\
\hline $\begin{array}{l}\text { Traditional } \\
\text { Market Orientation }\end{array}$ & 4.56 & 4.11 & 4.33 & 4.11 & 4.89 \\
\hline $\begin{array}{l}\text { Web-based } \\
\text { Market Orientation }\end{array}$ & 3.56 & 4.22 & 3.11 & 3.56 & 4.78 \\
\hline Difference & $\mathbf{- 2 2 . 0 0 \%}$ & $\mathbf{2 . 7 0 \%}$ & $\mathbf{- 2 8 . 0 0 \%}$ & $\mathbf{- 1 6 . 0 0 \%}$ & $\mathbf{- 2 . 2 5 \%}$ \\
\hline
\end{tabular}

However the actual presence of market oriented behaviours was not evident in any of the firm's web-based commerce behaviours. Not suprisingly, the firms did not access the 'how to' and 'principle' knowledge essential to the development of a web-based commerce competitive advantage. One firm did demonstrate delayed (three years post adoption) market orientated behaviours. They engaged in cooperative strategies and business model development and were able to clearly articulate the needs and wants of their web-based customers.

Across all the firms, resource constraints related to time and finances were offset through the acceptance of adoption incentives/assistance during their initial adoption of web-based commerce development. However, the most prevailing difficulty experienced across the firms was access to information sources through which 'how to' and 'principle' knowledge could be obtained and incorporated into the development of web-based commerce. The ability of local ISPs to act as 'technology linkers' was clearly beyond the scope of their capabilities, thereby providing tacit support for Plume (2001) who notes a significant challenge confronts webbased commerce in the form of knowledge integration. Specifically, this challenge is to the ability of firms (or external persons, such as ISPs) to successfully integrate traditional marketing practices with new technological opportunities to create value that is supportive of a sustainable competitive advantage. By and large, access to new value creating activities was not observed.

Despite the firms demonstrating the capability to develop a sustainable competitive advantage in 'traditional' commerce through the involvement of customers and channel members, such parties were reduced to mere spectators during their initial development of web-based commerce. It was observed in one case (which also demonstrated superior market-orientated behaviours) that when customers were transformed from spectators to participants, an increased understanding of the potential of web-based commerce did in fact occur. However, the 
web-based value observed (communication \& research efficiencies), was internalised within the firms, not shared with customers or channel members. While web-based value received exceeded the perceived cost of adoption (time \& effort), it was insufficient to lay the foundation to a future competitive advantage.

\section{DISCUSSION}

This research sought to identify possible reasons for the marked discrepancy between small firm implementation of web-based commerce and its ability to create incremental value for firms and their customers. The research findings identify several major implications for academia and small firm practitioners engaged in web-based commerce. Firstly regarding academia, the application of a firm's market orientation, its nature, measurement, and value during web-based commerce adoption require further consideration. Secondly, the unsuccessful acquisition, and therefore conversion of adoption information into adoption knowledge by small firms represents a major hurdle to the optimal adoption of web-based commerce.

\section{The Role of Market Orientation}

As the central driver of the adoption model, market orientation was argued to be responsible for developing a rich knowledge base, reflective of customers needs (expressed and latent), marketplace opportunities, and the technologies that will connect the entities. Without such knowledge, firms may not sense the desired benefits of their present and future customers required to identify value-creating activities supportive of a competitive advantage. A clear discrepancy was obtained between recorded market orientation measurements using Pelham and Wilson's (1996) scale and observations of actual firm behaviours. The firms, while claiming to have developed strategies based upon an understanding of their web-based customers behaviours (surveys), demonstrated no strategic actions related to developing knowledge of the customers, technologies and markets associated with web-based commerce (observations). The first concern relates to the application of the firm's market orientation.

As a pre-existing intangible resource, a firm's market orientation must be maintained and applied to contribute value to the firm. Market orientation, intrinsically reflective of a firm's culture (Hunt \& Morgan, 1995), is a source of value through application, rather than merely through possession (Prahalad \& Hamel, 1990). The absence of observable market-oriented behaviours restricted the empirical testing of the normative adoption model's application. The apparent failure to transfer the observed market-oriented behaviours from 'traditional' commerce to web-based commerce would appear related to the firm's lack of direction and knowledge developing web-based capabilities.

The very of nature of a firm's market orientation may well be challenged by new learning processes inherent to web-based commerce. Slater (2001) suggests that a firm's established market orientation must evolve to ensure greater market sensing in the face of significant market change. Slater notes that a future challenge for firms desirous of developing an e-market orientation is to stay connected to their customers. This echo's the literatures consistent 'listen to the customer, understand the customer, and provide a solution for the customer' proclamation for market-orientedness. The assumption being that market orientation is dependent upon a oneway linear relationship between customers, marketing, and the technologies employed to provide solutions.

However, the research findings lend support to the proposition of Wrenn (1997) that the construction and application of the market orientation construct may not be so straightforward. The firms found difficulty gaining access and understanding of their customers' needs and wants. As such, the traditional interpretational role of marketing simply did not occur. Consequently, technologies, be they products, processes, or a combination of both, did not eventuate to solve customer needs and wants. Wrenn further asserts that a non-linear relationship between the customer, marketing and technologies (Kotler, 1997) is required to translate technological attributes into customer benefits to sustain a market orientation during times of complex technical change (i.e. the Internet). The suggestion is that a far more dynamic role for marketing may be required to maintain or establish market-orientated behaviours within an environment influenced by rapid technological change.

It appears the role of market orientation during stage two was negatively impacted by the exclusion of customer's needs, wants and consumer behaviour information from the adoption process. The absence of consideration for customer needs during the development process may produce sub-optimal outcomes, limiting internal efficiencies rather than the incremental long-term value.

However, the activities of one firm over the eight months preceding the data collection period provides evidence of the valuable role customers contribute to market orientated firms in their adoption of web-based commerce. The firm developed close relationships with web-based customers in the North American market. In addition to being the only firm to record an increased web-based market orientation, they were also the only firm to articulate a clear understanding of their web-based customers' preferences and buying behaviour, market opportunities and the application of technology for web-based commerce. Along with an increased web-based market orientation (the survey), obvious market-oriented behaviours were observed. For example, the firm 
developed a database through which valuable customer information of preferences was recorded and regularly updated, providing the firm with a longitudinal record for customer profiling. The firm also engaged in cooperative strategies to acquire 'how to' knowledge through sharing the cost of technical training. As such the firm's adoption behaviours (albeit three years post adoption) provide partial support for stages two and three. The firm is using market-oriented behaviours to acquire a greater understanding of their customers and using cooperative practices to enhance such behaviours.

Finally, the case method produced an inconsistency between measured and observed market oriented behaviours. The recorded levels of web-based market orientation appear to reflect 'anticipated' future actions, rather than 'actual' behaviours. The firms appeared unable to separate their beliefs concerning what they actually do in a traditional sense compared to what that actually do in a web-based sense. Given the prominence of quantitative methods that employ surveys to measure market orientation, the findings cast a shadow over the accuracy and reliability of such methods. The findings lend support to the contentions of Rouse and Daellenbach (1999) that a greater understanding of the actual contribution of such intangible firm resources should occur from within, rather than outside firms.

\section{Knowledge acquisition and development difficulties}

A recurrent process throughout the web-based adoption model is the acquisition of market intelligence related to target markets, marketplaces and technologies and its conversion into knowledge. With the exception of one firm's delayed behaviours, the firms have not acquired such information, and therefore lacked a sufficient knowledge base upon which to build a web-based commerce platform. As previously discussed, the firms did not utilise their observed traditional market oriented behaviours during adoption of web-based commerce.

Three interrelated factors appear to have contributed to the firm's insufficient knowledge base. Firstly, an inability to visualise new sources of value and alternative structures that would be complementary to their existing value chains. Secondly, an over reliance upon they're respective ISPs/advisors to perform a technology linking role, and therefore an apparent lack of enthusiasm to explore the new web-based landscape themselves. Lastly, the firm's individual lack of absorptive capacity appears to have hampered what little efforts have been made to learn about web-based commerce opportunities.

\section{The lack of vision}

Sawhney and Zabin (2001) posit that many firms may be constrained by assumptions, inherited from their past that restrict their view of the future. Despite the literature's expectation that market oriented firms will challenge past assumptions through generative learning processes, an e-vision was not visualised during adoption. As such, no consideration was given to visionary architectural change, but rather, reliance was upon modifying the past. The result reflects an ignorance as to the need for 'how to' and 'principle' knowledge. Overall the initial approach appears very much a case of "if you don't know where you're going, any road will take you there" (Sawhney \& Zabin, 2001, p 11). The findings are consistent with the conclusions of Chaston, Badger, Mangles, and Salder-Smith, (2001) that perhaps small firms underestimate the need for planning prior to adopting webbased commerce.

\section{The quasi-technology linker}

The firms relied heavily on external ISPs/advisers to facilitate the development of web-based commerce at the expense of using their own knowledge of existing customers needs. Subsequent interviews with the relevant ISPs confirmed that they had neither the ability, nor the desire to provide 'how to' and 'principle' knowledge. Therefore, the opportunity to develop a value proposition derived from customer participation was lost, along with the value of the firm's pre-existing market orientation. The lesson to be learnt would seem to be to empower customers as co-architects of future value, and the systems that deliver that value. This would allow the ISPs to implement what is possible from an architectural perspective, rather than what is current thinking from an engineering perspective.

\section{Individual absorptive capacity}

Absorptive capacity can be defined as the "routines and processes by which firms acquire, assimilate, transform, and exploit knowledge to produce a dynamic organizational capability" (Zahra \& George, 2002), or simply, the ability to acquire and strategically use 'how to' and 'principle' knowledge. The firms lacked intensity, speed, and direction in their observed efforts to acquire external knowledge to the detriment of their ability to take possession of 'how to' and 'principle' knowledge. This appears to indicate the difficulty in transferring a market 
orientation from 'traditional' to web-based commerce without a guiding e-vision. It also perhaps reflects the difficulty of acquiring knowledge from such a novel and challenging domain.

\section{CONCLUSION}

In summary, the overall research findings support the research of Chau and Lawrence (1998) who found little evidence of enthusiasm to actively pursue literature, or advice, regarding web-based commerce by Tasmanian firms who had adopted web-based commerce. Without engaging in ongoing market oriented behaviours (gathering, dissemination and strategic use of information), the value of a market orientation is significantly decreased. Mere prior possession of the resource is not sufficient to contribute future value, it must be engaged to ensure knowledge is first gathered and disseminated within the firm and it's strategic partners.

This research, through the development of a normative web-based adoption model sought to examine the influence of a firm's market orientation to assist in the development of a web-based competitive advantage. It was theorised that market-orientated firm behaviours were essential requirements to optimising the development of web-based commerce in small firms within which resource (time, finances and knowledge) constraints commonly occur. That only one firm was satisfied with their adoption of web-base commerce, and that they were the only firm to exhibit market-orientated behaviours (albeit three years post adoption), provides partial support for the role of market orientation during web-based commerce adoption. This research has highlighted the difficulties in maintaining and/or developing a market orientation in environments influenced by rapid technological change. Given the significant contribution of small firms to the Australian economy (Gare, 2001), it is imperative further research examine the learning processes that contribute to the development of specific intelligence upon which incremental growth and future web-based competitive advantages are dependent.

\section{REFERENCES}

Afuah, A. and Tucci, C. L. (2001) Internet Business Models and Strategies, Sydney: McGraw-Hill Irwin.

Amit, R. and Zott, C. (2001) "Value creation in e-business", Strategic Management Journal, Vol 22 (6-7), 493-520.

Armstrong, L. and Hagel, J. (1996) "The real value of on-line communities", Harvard Business Review, Vol 74 (3), 134-141.

Australian Bureau of Statistics. (1999) Communications and Information Technology: Household use of

Information Technology, http://www.abs.gov.au, Catalogue Number 81146.0, (Accessed 21 October 2001).

Babbie, E. (1999) The Basics of Social Research, Melbourne: Wadsworth Publishing Company.

Brandenburger, A. M. and Nalebuff, B. J. (1995) "The right game: Use game theory to shape strategy", Harvard Business Review, Vol 73 (4), 57-71.

Chappell, C., \& Feindt, S. 1999. Analysis of E-Commerce Practice in SMEs, http://www.kite.tsa.de/, (Accessed 12 September 2001).

Chaston, I., Badger, B., Mangles, T. and Sadler-Smith, E. (2001) "The Internet and e-commerce: An opportunity to examine organisational learning in progress in small manufacturing firms”, International Small Business Journal, Vol 19 (2), 134-147.

Chau, S. and Lawrence, K.L. (1999) Electronic Commerce Knowledge, Capabilities, and Utilisation: The

Tasmanian Perspective, Proceeding of Collector' 98, University of New South Wales.

Cohen, W.M. and Levinthal, D.A. (1990) "Absorptive capacity: A new perspective on learning and innovation”, Administrative Science Quarterly, Vol 35, 128-152.

Day, G.S. (1999) “Creating a market-driven organisation”, Sloan Management Review, Vol 41 (1), 23-34.

Drucker, P.F. (1985) Innovation and Entrepreneurship, New York: Harper and Row.

Enders, A. and Jelassi, T. (2000) "The converging business models of Internet and bricks-and-mortar retailers", European Management Journal, Vol 18 (5), 542-550.

Gare, S. (2001) "Herded, bossed and cajoled, then milked", The Australian, 14 July 2001.

Glazer, R. (1991) "Marketing in an information intensive environment: Strategic implications of knowledge as an asset", Journal of Marketing, Vol 55, 1-19.

Hamill, J. (1997) "The Internet and international marketing", International Marketing Review, Vol 14 (5), 300-323.

Hoffman, D. L. and Novak, T. P. (1997) “A new marketing paradigm for electronic commerce”, The Information Society, Vol 13 (1), 43-55.

Hunt, S.H. and Morgan, R.M. (1995) "The comparative advantage theory of competition", Journal of Marketing, April, Vol 59, 1-15.

Kotler, P. (1997) Marketing Management: The Millennium Edition, Sydney: Prentice Hall. 
Lado, A.A., Boyd, N.G. and Hanlon, S.C. (1997) "Competition, cooperation, and the search for economic rents: A syncretic model”, Academy of Management Review, Vol 22 (1), 110-141.

McLennan, W. (1999) Small Business in Australia, ABS Catalogue No. 1321.0.

McWilliams, A. and Gray, S.R. (1995) "Understanding quasi integration”, Journal of Business Strategies, Vol 11, 171-195.

Mintzberg, H. (1990) "The Design School: Reconsidering the basic premises of strategic management", Strategic Management Journal, Vol 11 (3), 175-195.

Morgan, R.E., Katsikeas, C.S. and Appuh-Adu, K. (1998) "Market orientation and organisational learning", Journal of Marketing Management, Vol 14, 353-381.

Pelham, A.M. and Wilson, D. (1996) "A longitudinal study of the impact of market structure, and market orientation culture on dimensions of small-firm performance", Journal of the Academy of Marketing Science, Vol 24 (1), 27-43.

Peterson, R.T. (1989) "Small business adoption of the marketing concept vs. other business strategies", Journal of Small Business Management, Vol 27 (1), 38-46.

Plume, H. (2001) Survival of the e-Fittest, http://www.capcollege.bc.ca/admin/Formedia/2001releases/ebiz.html. (Accessed 5 August 2001).

Poon, S. and Strom, J. (1997) An Australia-UK Study of Small Firm Internet Use, Proceedings of the 1997 International Management Development Association Conference, Seoul, Korea, 316-323.

Poon, S. and Swatman, P.M.C. (1999) "An exploratory study of small business Internet commerce issues", Information \& Management, Vol 35, 9-18.

Porter, M.E. (1985) Competitive Advantage, New York: Free Press.

Prahalad, C.K. and Hamel, G. (1990) "The core competence of the corporation”, Harvard Business Review, Vol 68 (3), 79-91.

Rayport, J.F. \& Jaworski, B.J. (2001) e-Commerce, Sydney: McGraw-Hill/Irwin.

Rogers, E.M. (1995) Diffusion of Innovations, $4^{\text {th }}$ edition, New York: The Free Press.

Rouse, M.J. and Daellenbach, U.S. (1999) "Rethinking research methods for the resource-based perspective: Isolating sources of sustainable competitive advantage", Strategic Management Journal, Vol 20 (5), 487494.

Sanchez, R. (1997) "Preparing for an uncertain future: Managing for strategic flexibility", International Studies of Management \& Organisation, Vol 27 (2), 71-95.

Slater, S.F. (2001) "Market orientation at the beginning of a new millennium", Managing Service Quality, Vol $11(4), 230-232$.

Slater, S.F. and Narver, J.C. (1994) "Does competitive environment moderate the market orientation performance relationship”, Journal of Marketing, January, Vol 58, 46-55.

Slater, S.F. and Narver, J.C. (1998) "Customer-led and market-orientated: Let's not confuse the two", Strategic Management Journal, Vol 19 (10), 1001-1006.

Sawhney, M. \& Zabin, J. (2001) The Seven Steps to Nirvana, Sydney: McGraw-Hill.

Timmers, P. (1998) "Business models for electronic markets", Electronic Markets, 8 (2), 3-8. www.electronicmarkets.org, (Accessed 2 June 2001).

Wrenn, B. (1997) Reality based market orientation, Proceeding of Marketing Management Association, Chicago, IL: Marketing Management Association and Department of Marketing, School of Business, Indiana State University.

Yellow Pages Business Index. (2001) E-commerce and Computer Technology, http://www.corporate.pacificaccess.com.au, (Accessed 13 October 2001)

Yin, R.K. (1994) Case Study Research Design and Methods, $2^{\text {nd }}$ edition, Thousand Oaks, California: Sage Publications.

Zahra, S.A. and George, G. (2002) “Absorptive capacity: A review, reconceptualization, and extension”, Academy of Management Review, Vol 27 (2), 185-203. 